CENDEKIA, Vol. 9, No. 1, April 2015

p ISSN: 1978 2098; e ISSN: 2407 8557; Web: cendekia.pusatbahasa.or.id Pusat Kajian Bahasa dan Budaya, Surakarta, Indonesia

Zahro, Aminatul. 2015. Total Quality Management: Capaian Kualitas Output melalui Sistem Kontrol Mutu Sekolah. Cendekia, 9(1): 79 94.

\title{
TOTAL QUALITY MANAGEMENT: CAPAIAN KUALITAS OUTPUT MELALUI SISTEM KONTROL MUTU SEKOLAH
}

\author{
Aminatul Zahroh \\ Pascasarjana IAIN Tulungagung \\ Jl. Mayor Sujadi Timur 46 Tulungagung, Jatim \\ Email: aminatulzahroh@gmail.com
}

\begin{abstract}
This paper describes Total Quality Management (TQM) that deescribes how quality would be achieved through control porcess in the education practices. Quality refers to structured process to improve the outputs. To accomplish standardized quality of an output, all school components are required in a networking involving principals, teachers, students, staffs, and students-parents. Education quality should serve input and porcess to achieve standardized quality of the output. Essentially, TQM is a core management to see quality control from process into quality.
\end{abstract}

Keywords: Total quality management, output, quality control.

Pendidikan merupakan sistem dan cara meningkatkan kualitas hidup manusia dalam segala aspek kehidupan manusia.Pendidikan merupakan sarana yang paling efektif dan efisien untuk mentransformasikan ilmu pengetahuan, budaya dan lain sebagainya dari satu generasi ke generasi berikutnya.Pendidikan itu mewakili sebuah aspirasi dari nilai atau mutu yang telah dicita-citakan. Perkembangan dunia pendidikan dewasa ini begitu cepat. Sejalan dengan kemajuan teknologi dan globalisasi, dunia pendidikan sedang diguncang oleh berbagai perubahan sesuai dengan tuntutan dan kebutuhan masyarakat, serta ditantang untuk dapat menjawab berbagai permasalahan lokal dan perubahan global yang terjadi begitu pesat. Era globalisasi yang ditandai dengan persaingan kualitas atau mutu, menuntut semua pihak dalam berbagai bidang dan sektor pembangunan untuk senantiasa meningkatkan kompetensinya. Hal tersebut mendudukkan betapa pentingnya upaya peningkatan kualitas pendidikan baik secara kuantitatif maupun kualitatif yang harus dilakukan terus-menerus.

Dunia pendidikan saat ini sedang mengalami masalah yang cukup berat. Masalah tersebut terkait dengan mutu pendidikan. Saat ini tingkat mutu pendidikan di Indonesia masih sangat rendah dan jauh dari harapan masyarakat sebagai pengguna (stakeholder) dan konsumen pendidikan. Salah satu hal yang menunjukkan bahwa rendahnya mutu pendidikan yaitu masih rendahnya kualitas atau mutu lulusan (Syafarudin, 2002:19). Maka dari itu lembaga pendidikan harus mempersiapkan diri dengan meningkatkan mutu dan kualitasnya.

Mutu pendidikan di Indonesia memang dinilai semakin merosot. Mutu pendidikan Indonesia kalah dengan Malaysia. Dahulu Indonesia jauh berada di atas Malaysia. Faktor penyebab rendahnya mutu berasal dari berbagai faktor baik internal maupun eksternal. Upaya perbaikan mutu terus dilakukan, akan tetapi pada kenyataannya kurang atau bahkan tidak berhasil. Hal ini disebabkan oleh pertama, penggunaan strategi pendidikan yang bersifat input 
CENDEKIA, Vol. 9, No. 1, April 2015

p ISSN: 1978 2098; e ISSN: 2407 8557; Web: cendekia.pusatbahasa.or.id

Pusat Kajian Bahasa dan Budaya, Surakarta, Indonesia

Zahro, Aminatul. 2015. Total Quality Management: Capaian Kualitas Output melalui Sistem Kontrol Mutu Sekolah. Cendekia, 9(1): 79 94.

oriented. Kedua, pengelolaan pendidikan yang masih bersifat macro oriented (M. Ali Hasan dan Mukti Ali. 2003:207).

Melihat hal tersebut, pemerintah mengeluarkan berbagai kebijakan terkait peningkatan mutu pendidikan. Pertama, dengan memperbaharui sistem pendidikan nasional dengan UU No 20 Tahun 2003. Kedua, menetapkan 8 standar nasional pendidikan dengan PP No. 19 Tahun 2005 yang berisi standar isi, standar proses, standar kompetensi lulusan, standar pendidik dan tenaga kependidikan, standar sarana dan prasarana, standar pengelolaan, standar pembiayaan, dan standar penilaian pendidikan. Ketiga, adanya Permendiknas No. 22 Tahun 2006 tentang Standar Isi untuk satuan pendidikan Dasar dan Menengah. Keempat, adanya Permendiknas No. 23 Tahun 2006 tentang Standar Kompetensi Lulusan untuk Satuan Pendidikan Dasar dan Menengah. Bebagai kebijakan yang telah dikeluarkan pemerintah tersebut memiliki tujuan untuk meningkatkan mutu pendidikan.

Dalam upaya peningkatan mutu pendidikan pada tingkat satuan pendidikan manajemen sekolah mempunyai peran yang cukup signifikan. Manajemen merupakan suatu hal penting yang mampu mempengaruhi seluruh aspek termasuk sekolah. Implementasi dari manajemen harus dilakukan secara total dan menyeluruh agar tidak terjadi hal-hal yang keluar dari visi, misi dan tujuan sekolah, maka dari itu diperlukan total quality management atau yang biasa dikenal dengan TQM.

TQM adalah suatu pendekatan dalam usaha memaksimalkan daya saing melalui proses perbaikan terus-menerus atas jasa, manusia, proses dan lingkungannya (Fandy Tjiptono dan Anastasia Diana, 2003:4). Dengan adanya TQM ini sekolah mampu mengenali kemampuan, kelebihan dan sekaligus kekurangannya.

Sedangkan implementasi dari TQM dalam mewujudkan pendidikan yang berkualitas yang didukung oleh tingginya mutu/kualitas output di sekolah adalah dengan memperbaiki semua aspek baik itu kelengkapan sarana prasarana, profesionalisme guru, termasuk juga mutu lulusan (output). Berbicara tentang pendidikan yang berkualitas tidak akan pernah lepas dari upaya sekolah dalam meningkatkan mutu baik input, proses maupun outputnya. Setiap sekolah memiliki cara atau model tersendiri dalam mengontrol mutu lulusannya. Berbagai upaya yang dilakukan oleh sekolah dalam peningkatan mutu tidak akan berarti kalau tidak diikuti dengan pengawasan/pengontrolan terhadap mutu lulusan.Dalam mewujudkan dan mengedepankan kualitas output, maka TQM menggunakan cara yang efektif yaitu dengan sistem kontrol mutu (quality control).

Kontrol mutu adalah suatu sistem untuk mendeteksi terjadinya penyimpangan kualitas output yang tidak sesuai dengan standar (J. M. Juran, 1989: 165). Melalui sistem kontrol mutu inilah lulusan yang jauh dari standar akan terdeteksi dengan baik, sehingga kegagalan mampu diminimalisir dengan baik. Upaya untuk meningkatkan mutu pendidikan terus dilakukan baik yang berorientasi akademik maupun ketrampilan, karena pendidikan dianggap bermutu jika mampu melahirkan keunggulan akademik dan keunggulan ekstrakurikuler yang berupa ketrampilan. Keunggulan akademik dan keunggulan ekstrakurikuler inilah yang memabawa pada kualitas mutu lulusan. 
CENDEKIA, Vol. 9, No. 1, April 2015

p ISSN: 1978 2098; e ISSN: 2407 8557; Web: cendekia.pusatbahasa.or.id

Pusat Kajian Bahasa dan Budaya, Surakarta, Indonesia

Zahro, Aminatul. 2015. Total Quality Management: Capaian Kualitas Output melalui Sistem Kontrol Mutu Sekolah. Cendekia, 9(1): 79 94.

\section{TOTAL QUALITY MANAGEMENT (TQM)}

Manajemen adalah suatu proses pemecahan masalah sehingga langkah-langkah manaajemen tidak ubahnya sebagaimana langkah-langkah pemecahan masalah. Manajenen atau pengelolaan merupakan komponen integral dan tidak dapat dipisahkan dari proses secara keseluruhan. Manajemen berasal dari kata to manage yang artinya mengurus, mengatur, melaksanakan dan mengelola (Cardaso Gorton Faustno, 2002:1). Management as the proses of working with and through individuals and groups and other resources to accomplish organazational goals (Paul Hersey dan Blachard Kenneth H, 1998:5).

Selanjutnya Terry dalam bukunya yang berjudul Principles of Management mendefinisikan, Management is a distinct process consisting of planning, organizing, actuating, and controlling, performed to determine and accomplish a stated objectives by the use of human being and other (Terry George, 1977:5).Manajemen adalah The process of planning, organizing, leading, and controlling the work of organization members and of using all available organizational resources to reach stated organizational goals (James A.F Stoner, 1995:7). Hal senada juga diungkapkan oleh Daft bahwa Management is the attainment of organization goals in an effective and efficient manner through planning, organizing, leading, and controlling organizational resources(Richard L. Daft, 1991:5).

TQM ialah suatu pendekatan dalam usaha memaksimalkan daya saing melalui perbaikan terus-menerus atas jasa, manusia, produk dan lingkungan. Di dalam TQM terdapat serangkaian usaha untuk memaksimalkan semua fungsi daripada organisasi dalam falsafah holistis yang dibangun berdasarkan konsep mutu, kerja tim, efektivitas, dan prestasi serta kepuasan pelanggan (Aminatul Zahroh, 2014:92).

TQM adalah suatu pendekatan dalam usaha memaksimalkan daya saing melalui proses perbaikan terus-menerus atas jasa, manusia, proses dan lingkungannya (Fandy Tjiptono dan Anastasia Diana, 2003:4). Sedangkan implementasi dari TQM adalah semua fungsi dari organisasi sekolah kedalam falsafah holistis yang dibangun berdasarkan konsep mutu, kerja tim, produktifitas dan prestasi sertakepuasan pelanggan (Husaini Usman, 2006:458).

Sedangkan lima langkah manajemen yaitu: 1) Setting derection, aims and objectives. 2) Planning how progress will be made or a goal achieved. 3) Organizing available resources (people time, materials) so that the goal can be ahcieved in the planned way. 4) Controlling the process. (i.e. measuring achievement againts the plan and taking corective action where appropriate). 5) Setting and improving organisational standards (Bush, T. \& Coleman, t.t: 4). Dalam meningkatan mutu pendidikan diperlukan strategi yaitu peningkatan mutu pendidikan yang berorientasi ketrampilan (broad based education) dan peningkatan mutu pendidikan berorientasi akademik (hight based education) (A. Malik Fadjar, 2005:269).

Ini menunjukan bahwa TQM merupakan suatu sistem manajemen yang menyangkut mutu sebagai strategi dan usaha yang berorientasi pada kepuasan pelanggan dengan melibatkan seluruh anggota organisasi. Di dalam total quality management yang diutamakan adalah: Pertama, Total. Total dalam TQM merupakan strategi organisasional menyeluruh yang melibatkansemua jenjang dan jajaran manajemen dan karyawan, bukan hanya pengguna akhir dan pembeli eksternal saja, tetapi juga pelanggan internal, pemasok, bahkan personalia pendukung. Kedua, Kualitas. Kualitas di dalam TQM lebih menekankan pelayanan kualitas, bukan sekadar produk bebas cacat. Kualitas didefinisikan oleh pelanggan, ekspektasi 
CENDEKIA, Vol. 9, No. 1, April 2015

p ISSN: 1978 2098; e ISSN: 2407 8557; Web: cendekia.pusatbahasa.or.id

Pusat Kajian Bahasa dan Budaya, Surakarta, Indonesia

Zahro, Aminatul. 2015. Total Quality Management: Capaian Kualitas Output melalui Sistem Kontrol Mutu Sekolah. Cendekia, 9(1): 79 94.

pelanggan bersifat individual, tergantung pada latar belakang sosial ekonomis dan karakteristik demografis. Ketiga, manajemen. Manajemen di dalam TQM merupakan suatu pendekatan manajemen, bukan pendekatan teknis pengendalian kualitas.

\section{Prinsip-prinsip Total Quality Management}

Implementasi dari TQM di sekolah ada lima prinsip yang digunakan sekolah. Lima prinsip tersebut adalah Pertama, fokus pada pelanggan. Kedua, keterlibatan total. Ketiga, pengukuran. Keempat, komitmen. Kelima, perbaikan berkelanjutan (Jerome S. Arcaro Terjemahan Yosai Triantara, 1995:15).

Lebih lanjut dalam TQM ada empat prinsip. Prinsip tersebut yaitu kepuasan pelanggan, respek terhadap setiap orang, manajemen berbasis fakta dan mengadakan perbaikan yang bersifat terus menerus. Dalam TQM terdapat dua pelanggan yaitu internal dan eksternal. Pelanggan internal terdiri dari guru, karyawan dan peserta didik. Sedangkan pelanggan eksternalnya terdiri dari komite sekolah, masyarakat, pemerintah, dan orang tua peserta didik.

Pada prinsipnya TQM terus mengadakan perbaikan, oleh karena itu, untuk mensukseskan TQM dibutuhkan sebuah manajemen pengendalian mutu yang sempurna. Artinya sebuah perencanaan dan pelaksanaan harus dikendalikan agar tujuan atau mutu yang diharapkan dapat terwujud dengan baik. Sehingga inti dari TQM adalah pengendalian manajemen menuju manajemen yang bermutu dan berkualitas.

\section{Implementasi TQM dalam Mewujudkan Output yang Berkualitas}

Untuk mencapai perbaikan mutu yang berkelanjutan, maka diperlukan strategi untuk meningkatkan mutu. Strategi tersebut digunakan sebagai media untuk mengidentifikasi dan memecahkan persoalan. Strategi tersebut antara lain dengan brainstorming. Brainstormingini dapat meningkatkan kreatifitas dalam mengembangkan ide-ide secara cepat dan tepat. Untuk membantu brainstorming dalam peningkatan mutu, maka diperlukan adalah: Pertama, teknik afinitas jaringan kerja. Teknik ini digunakan untuk mengelompokkan sejumlah ide yang bertujuan untuk mengidentifikasi ide-ide yang memiliki keterkaitan satu sama lain (Edward Sallis. 2006:199-200). Kedua, diagram tulang ikan (diagram Ishikawa). Teknik ini menganjurkan tim untuk memetakan seluruh faktor yang menyebabkan terjadinya pada hasil yang diinginkan. Tujuannya adalah untuk mendata seluruh faktor yang mempengaruhi mutu. Ketiga, analisis kekuatan lapangan (force field analysis) adalah analisis untuk mempelajari situasi yang memerlukan perubahan termasuk perubahan di sekolah. Keempat, flowcharts. Flowcharts ini merupakan teknik yang biasa digunakan dalam TQM.

Untuk mewujudkan kualitas mutu lulusan diperlukan program peningkatan mutu dengan mengaplikasikan empat teknik. Empat tehnik tersebut adalah review, benchmarking, quality assurance, dan quality control (Falah Yunus, 2007:3).

\section{School review}

School reviewadalahproses yang dilaksanakan oleh seluruh komponen sekolah dalam mengadakan kerjasama dengan tenaga ahli, masyarakat dan orang tua dalam rangka mengevaluasi sekaligus menilai terkait efektivitas dari sekolah berikut mutu lulusannya 
CENDEKIA, Vol. 9, No. 1, April 2015

p ISSN: 1978 2098; e ISSN: 2407 8557; Web: cendekia.pusatbahasa.or.id Pusat Kajian Bahasa dan Budaya, Surakarta, Indonesia

Zahro, Aminatul. 2015. Total Quality Management: Capaian Kualitas Output melalui Sistem Kontrol Mutu Sekolah. Cendekia, 9(1): 79 94.

(output). School review ini berfungsi untuk mengadakan perbaikan sekolah di tahun yang akan datang.

\section{Benchmarking}

Benchmarking adalah cara yang digunakan untuk menetapkan standar dan target yang akan dicapai dari mutu dalam suatu periode tertentu. Penerapan benchmarkingdalam dunia pendidikan berfungsi untuk mengetahui ancaman, tantangan, kelemahan, keunggulan dan prestasi lembaga pendidikan atau sekolah baik internal maupun eksternal. Benchmarkingini juga terus mengadakan perbaikan terus menerus (continuous improvement) dalam mewujudkan pendidikan yang bermutu menuju lulusan (output) yang berkualitas.

\section{Penjaminan mutu (quality assurance)}

Penjaminan mutu (quality assurance) pendidikan adalah seluruh kegiatan terencana dan sistematis yang diimplementasikan di dalam sistem mutu yang mempelajari tentang proses penetapan dan pemenuhan standar mutu pendidikan dalam proses pengelolaan secara konsisten dan berkelanjutan, sehingga konsumen, produsen, dan pihak lain yang berkepentingan memperoleh kepuasan akan produk atau layanan yang diberikan(Ali Winata, 2006:55).Lebih lanjut bahwa penjaminan mutu (quality assurance) pendidikan merupakan merupakan kegiatan sistematik dan terpadu oleh satuan atau program pendidikan, penyelenggara satuan atau program pendidikan, pemerintah daerah, pemerintah, dan masyarakat untuk menaikkan tingkat kecerdasan kehidupan bangsa melalui pendidikan(Dedy Mulyasana, 2011:129).

Penjaminan mutu ini dapat mendeteksi dan memonitoring segala penyimpangan yang ada di sekolah. Penjaminan mutu ini jugamemberikan informasi kepada orangtua peserta didik dan sekaligus memberikan jaminan bahwa sekolah senantiasa (akan berusaha) memberikan pelayanan terbaik bagi peserta didiknya sehingga menjadi lulusan yang berkualitas, cakap, dan terampil.

\section{4. $\quad$ Kontrol mutu (quality control)}

Kontrol mutu atau yang biasa dikenal dengan quality control adalah suatu sistem untuk mendeteksi terjadinyapenyimpangan kualitas output yang tidak sesuai dengan standar. Quality control memerlukan indikator kualitas yang jelas dan pasti, sehingga dapatditentukan penyimpangan kualitas yang terjadi (J. M. Juran, 1989:165). Dalam melaksanakan kontol mutu ini diperlukan adanya kerjasama antara pihak lembaga pendidikan dengan kementrian terkait serta peran aktif dari masyarakat.

Keberhasilan aplikasi TQM di sekolah diukur dari: Pertama, tingkat kepuasan pelanggan baik internal maupun eksternal. Sekolah dikatakan berhasil jika mampu memberikan layanan sesuai harapan pelanggan. Dengan kata lain, keberhasilan sekolah dikemukakan dalam panduan manajemen sekolah apabila peserta didik merasa puas dengan layanan sekolah. Kedua, orangtua peserta didik merasa puas dengan layanan terhadap anaknya. Ketiga, pihak pemakai atau penerima lulusan merasa puas karena menerima lulusandengan kualitas tinggi dan sesuai harapan. Keempat, guru dan karyawan merasa puas dengan layanan sekolah. 
CENDEKIA, Vol. 9, No. 1, April 2015

p ISSN: 1978 2098; e ISSN: 2407 8557; Web: cendekia.pusatbahasa.or.id Pusat Kajian Bahasa dan Budaya, Surakarta, Indonesia

Zahro, Aminatul. 2015. Total Quality Management: Capaian Kualitas Output melalui Sistem Kontrol Mutu Sekolah. Cendekia, 9(1): 79 94.

Sekolah bisa menghasilkan lulusan yang bermutu apabila penyelenggaraan pendidikan mutunya juga terjamin. Mutu pendidikan akan terjamin ketika kepala sekolah melaksanakan fungsi kepemimpinannya dengan baik dan dibarengi komponen pendidikan yang berkualitas juga atau dalam bahasa lainnya adanya terjadi sinergitas yang berorientasi pada mutu pendidikan antara pemimpin dengan seluruh civitas akademika di lembaga pendidikan atau sekolah.

\section{KONTROL MUTU MENUJU KUALITAS OUTPUT}

Mutu adalah conformance to requirement, yaitu sesuai yang diisyaratkan atau distandarkan. Artinya suatu produk memiliki mutu apabila sesuai dengan standar mutu yang telah ditentukan. Standar mutu meliputi bahan baku, proses produksi dan produksi jadi (M. N. Nasution, 2001:16). Mutu adalah faktor keputusan mendasar dari pelanggan. Mutu digunakan untuk mengukur dan memperbaiki lulusan.

Pendidikan yang bermutu adalah pendidikan yang dapat menghasilkan keluaran, baik pelayanan, dan lulusan yang sesuai dengan kebutuhan atau harapan pelanggan (pasar)nya. Mutu dalam konteks pendidikan, berkaitan dengan upaya memberikan pelayanan yang paripurna dan memuaskan bagi para pemakai jasa pendidikan. Dalam sistem penyelenggaraan pendidikan, aspek mutu (quality) juga akan selalu berkaitan dengan bagaimana input peserta didik, proses penyelenggaraan pendidikan dengan fokus layanan peserta didik, sampai bagaimana output yang dihasilkan (Bedjo Sujanto, 2007:116). Maka dari itu, mutu dalam pendidikan dapat saja disebutkan mengutamakan pelajar atau program perbaikan sekolah yang mungkin dilakukan secara lebih kreatif dan konstruktif (Syafaruddin, 2002:35). Mutu dalam pendidikan memang dititik tekankan pada pelajar dan proses yang ada di dalamnya. Tanpa adanya proses yang baik, maka sekolah yang bermutu juga akan mustahil untuk dicapai.

Mutu dikelompokkan dalam lima dimensi yakni: Pertama, mutu sebagai hal yang luar biasa: mutu jenis ini jarang dipakai untuk menunjukkan visi atau misi perguruan tinggi karena terlalu berat menanggungnya. Mutu ini biasanya digunakan untuk menghargai seseorang perilakunya pada masa yang lalu. Kedua, mutu sebagai kesempurnaan dan konsistensi: perkataan center ofexcellence menunjukkan mutu jenis ini. Kriteria yang digunakan disiniadalah kriteria yang "sempurna". Mutu dalam dimensi ini digunakan oleh lembaga pendidikan dimasa lalu dan ada yang diteruskan hingga sekarang, lembaga pendidikan mendambakan mutu jenis ini karena hanya mutu jenis ini yang dianggap layak untuk diraih. Syarat tambahannya adalah bahwa mutu ini harus secara konsisten dipertahankan. Ketiga, mutu sebagai kecocokan dengan tujuan: mutu ini diukur dari tujuan lembaganya. Misalnya bila suatu perguruan tinggi mengatakan bahwa ia ingin menjadi research university, maka ia tidak menunjukkan mutunya jika perguruan tinggi tersebut tidak menghasilkan penelitian yang berkaliber internasional atau penemuan-penemuan yang dapatdipatenkan.Keempat, mutu sebagai hasil biaya (value for money) artinya mutu dapat pula ditentukan oleh biaya yang dikeluarkan untuk membuat produknya. Bila biaya sedikit, tetapi bermanfaat, produk tersebut dapat disebut bermutu, meskipun dalam banyak hal kalah dengan produk lain yang serupa tetapi harganya berlipat ganda. Kelima, mutu sebagai transformasi: transformasi atau perubahan merujuk pada produk sebelumnya. Bila produk sekarang lebih baik dari produk 
CENDEKIA, Vol. 9, No. 1, April 2015

p ISSN: 1978 2098; e ISSN: 2407 8557; Web: cendekia.pusatbahasa.or.id Pusat Kajian Bahasa dan Budaya, Surakarta, Indonesia

Zahro, Aminatul. 2015. Total Quality Management: Capaian Kualitas Output melalui Sistem Kontrol Mutu Sekolah. Cendekia, 9(1): 79 94.

yang lalu, meskipun dalam perbandingan dengan produk lembaga lain yang sudah terkenal masih kalah, maka produk itu dapat dianggap mempunyai mutu (Muhaimin, 2005:23).

Meskipun semua definisi tentang mutu memiliki kesamaan, yaitu: Pertama, mutu memenuhi harapan pelanggan (stakeholder). Kedua, mutu mencakup produk, jasa, manusia, proses dan lingkungan. Ketiga, mutu merupakan suatu kondisi yang selalu berubah misalnya: sesuatu yang dianggap bermutu saat ini mungkin akan dianggap kurang bermutu pada masa yang mendatang (Rinda Hedwig dan Gerardus Polla, 2006:2).

Berangkat dari beberapa definisi tersebut, maka dapat diketahui bahwa hal mendasar dalam mendefinisikan mutuadalah quality assurance, contract conformance andcostumer driven (Stephen Murgatroyd and Colin Morgan, 1994:45).

\section{Pengertian Kontrol Mutu Sekolah}

Kontrol mutu (quality control) adalah suatu sistem untuk mendeteksiterjadinya penyimpangan kualitas lulusan yang tidak sesuai dengan standar. Konsep ini berorientasi pada output untuk memastikan apakah mutu output sesuai dengan standar atau tidak (J. M. Juran, 1989:165).

Dalam rangka melaksanakan peningkatan kualitas pendidikan perlu melaksanakan metode yang dikenal dengan metode PDCA (plan, do, chek, action). Metode ini pertama kali dikembangkan oleh Sheward dan divisualisasikan oleh Deming, berupa siklus PDCA (Harjo Soedarmo, 1997:52).

Gambar 1. Siklus PDCA Deming

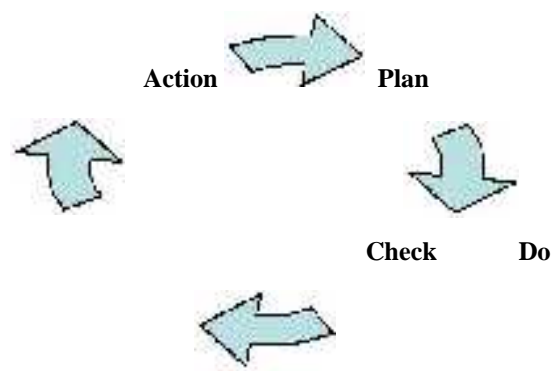

Berangkat dari siklus di atas, bisa diambil pengertian dengan beberapa tahapan yaitu:

1. Plan,berisi penentuan proses yang aman yang perlu diperbaiki,menentukan perbaikan apa yang dipilih, dan menentukan data dan informasi yang diperlukan untuk perbaikan proses.

2. Do, beirisi pengumpulan data dasar tentang jalannya proses,implementasi perubahan yang dikehendaki (skala kecil), mengumpulkan data untuk mengetahui perubahan (ada perbaikan atau tidak).

3. Check, berisi langkah pemimpin untuk menafsirkan hasilimplementasi (berhasil atau tidak) atau upaya pemimpin untuk memperoleh pengetahuan baru tentang proses yang berada dalam tanggung jawabnya.

4. Action, berupa pengambilan keputusan perubahan mana yang akandiimplementasikan, penyusunan prosedur baku, pelatihan ulang bagi anggota terkait, dan pemantauan secara kontinyu (Burhanuddin dkk., 2002: 21). 
CENDEKIA, Vol. 9, No. 1, April 2015

p ISSN: 1978 2098; e ISSN: 2407 8557; Web: cendekia.pusatbahasa.or.id Pusat Kajian Bahasa dan Budaya, Surakarta, Indonesia

Zahro, Aminatul. 2015. Total Quality Management: Capaian Kualitas Output melalui Sistem Kontrol Mutu Sekolah. Cendekia, 9(1): 79 94.

Dalam TQM dikenal istilah lingkaran mutu yang merupakan ciri penting dari metode kontrol mutu terpadu (Total Quality Control) Jepang yang dikemukakan oleh Ishikawa. Metode control mutu terpadu biasa dikenal dengan TQC. Berikut ini secara jelas dipaparkan mengenai mutu Ishikawa. Lingkaran mutu ishikawa ini merupakan lingkaran mutu pendidikan yang biasa digunakan oleh lembaga pendidikan atau sekolah. Didalam lingkaran mutu ini ada komponen yang saling terkait dalam usaha perwujudan mutu pendidikan.

\section{Gambar 2. Lingkaran Mutu Pendidikan}

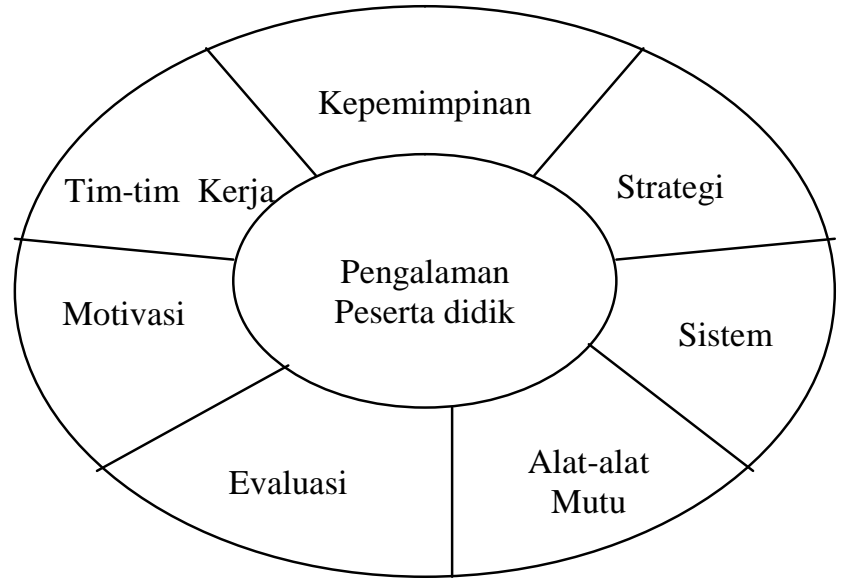

Dari gambar di atas, bahwa mutu merupakan usaha bersama yang harus diwujudkan oleh berbagai pihak di lembaga pendidikan atau sekolah. Mutu pendidikan merupakan citacita bersama seluruh pemikir dan praktisi pendidikan. Oleh karena itu, perbaikan mutu yang berkelanjutan harus menjadi strategi wajib dalam lembaga pendidikan atau sekolah. Dalam upaya peningkatan mutu sekurang-kurangnya ada tiga faktor utama, yaitu sebagai berikut: Pertama, kecukupan sumber-sumber pendidikan. Dalam hal ini meliputi kualitas tenaga kependidikan, biaya, dan sarana belajar. Kedua, mutu proses belajar mengajar yang dapat mendorong siswa belajar aktif. Ketiga, mutu keluaran dalam bentuk cakap pengetahuan, sikap, keterampilan, dan nilai-nilai (Nanang Fatah, 2000:90).

Untuk mewujudkan peningkatan mutu pendidikan diperlukan strategi yang berorientasi pada keterampilan dan orientasi akademik. Upaya peningkatan mutu tersebut bisa ditempuh melalui cara-cara berikut:

a. Quality assurance kepada semua lembaga pendidikan sehingga dapat mempersiapkan siswa untuk dapat tersaring pada saat dilakukan quality control melalui ujian nasional.

b. Menjamin kesejahteraan tenaga kependidikan sehingga mereka dapat hidup layak dan dapat memusatkan perhatiannya pada kegiatan belajar.

c. Mendorong daerah dan lembaga untuk dapat memobilisasi berbagai sumber dana dalam rangka meningkatkan mutu pelayanan pendidikan (Aminatul Zahroh, 2014:83).

Upaya perbaikan mutu harus dilakukan oleh seluruh komponen pendidikan. Perbaikan tersebut harus berorientasi pada pencapaian mutu. Semua program dan kegiatan pendidikan serta pembelajaran di lembaga pendidikan atau sekolah pada hakikatnya harus bisa diarahkan pada pencapaian mutu. Walaupun hingga sekarang ini, persoalan mutu masih menjadi 
CENDEKIA, Vol. 9, No. 1, April 2015

p ISSN: 1978 2098; e ISSN: 2407 8557; Web: cendekia.pusatbahasa.or.id

Pusat Kajian Bahasa dan Budaya, Surakarta, Indonesia

Zahro, Aminatul. 2015. Total Quality Management: Capaian Kualitas Output melalui Sistem Kontrol Mutu Sekolah. Cendekia, 9(1): 79 94.

pembahasan di tataran idealisme, belum menjadi realitas dalam lembaga pendidikan, sehingga mutu pendidikan ini benar-benar misterius. Maka dari itu, perlu dikerahkan semua pikiran, tenaga, dan strategi untuk bisa mewujudkan mutu tersebut dalam lembaga pendidikan atau sekolah. Keberhasilan daripada penerapan kontrol mutu memang tidak mudah, diperlukan komitmen dan kerjasama yang baik antara seluruh warga sekolah dan kerjasama dengan masyarakat.

\section{Indikator Mutu Pendidikan}

Mutu adalah faktor keputusan mendasar dari pelanggan. Mutu adalah sebuah proses terstruktur untuk memperbaiki keluaran yang dihasilkan (Jarome S. Arcaro, 2007:75). Pendidikan yang bermutu adalah pendidikan yang dapat menghasilkan keluaran, baik pelayanan, dan lulusan yang sesuai dengan kebutuhan atau harapan pelanggan (pasar)nya. Secara konseptual, mutu selalu berkaitan dengan pelanggan, pembeli, pemakai produk atau jasa yang dihasilkan oleh suatu lembaga maupun perseorangan.

Mutu dalam konteks pendidikan, berkaitan dengan upaya memberikan pelayanan yang paripurna dan memuaskan bagi para pemakai jasa pendidikan. Dalam sistem penyelenggaraan pendidikan, aspek mutu (quality) juga akan selalu berkaitan dengan bagaimana input peserta didik, proses penyelenggaraan pendidikan dengan fokus layananpeserta didik, sampai bagaimana output yang dihasilkan (Bedjo Sujanto, 2007:116). Maka dari itu, mutu dalam pendidikan dapat saja disebutkan mengutamakan pelajar atau program perbaikan sekolah yang mungkin dilakukan secara lebih kreatif dan konstruktif (Syafaruddin, 2002:35). Mutu dalam pendidikan memang dititik tekankan pada peserta didikdan proses yang ada di dalamnya. Tanpa adanya proses yang baik, maka sekolah yang bermutu juga akan mustahil untuk dicapai.

Pendidikan dianggap bermutu jika mampu menunjukkan keunggulan akademik dan ekstrakurikuler. Berkut ini akan dijelaskan satu per satu secara lebih detail. Pertama, input. Input adalah segala sesuatu yang harus tersedia karena dibutuhkan untuk berlangsungnya proses. Input meliputi: kebijakan mutu dan harapan, sumber daya (kesediaan masyarakat), berorientasipeserta didik, manajemen (pembagian tugas, perencanaan, kendali mutu, dan efisiensi). Kedua, proses. Proses merupakan berubahnya sesuatu menjadi sesuatu yang lain. Sesuatu yang berpengaruh terhadap berlangsungnya proses disebut input sedangkan sesuatu dari hasil proses disebut output. Ketiga, output. Output dapat dijelaskan bahwa output sekolah dikatakan berkualitas atau bermutu tinggi jika prestasi sekolah, khususnya prestasi belajar peserta didikmenunjukkan pencapaian yang tinggi dalam; prestasi akademik: NEM, lomba karya ilmiah, olimpiade, dan kejuaraan-kejuaraan yang lain. Dan prestasi non akademik: olahraga, kepramukaan, kesenian, kerajinan dan lain-lain (Abdul Rachman Shaleh, 2006:252253).

Mutu pendidikan sering diindikasikan dengan kondisi yang baik, memenuhi syarat, dan segala komponen yang harus terdapat dalam pendidikan. Komponen-komponen tersebut adalah masukan, proses, keluaran, tenaga kependidikan, sarana-prasarana dan biaya. Mutu pendidikan juga merupakan salah satu faktor penentu daya saing bangsa, sehingga untuk dapat tetap bisa bertahan dalam percaturan global, maka pendidikan yang bermutu mutlak diperlukan. 
CENDEKIA, Vol. 9, No. 1, April 2015

p ISSN: 1978 2098; e ISSN: 2407 8557; Web: cendekia.pusatbahasa.or.id

Pusat Kajian Bahasa dan Budaya, Surakarta, Indonesia

Zahro, Aminatul. 2015. Total Quality Management: Capaian Kualitas Output melalui Sistem Kontrol Mutu Sekolah. Cendekia, 9(1): 79 94.

Lembaga pendidikan dapat dikatakan bermutu, apabila prestasi sekolah khususnya prestasipeserta didik, menunjukkan pencapaian yang tinggi dalam: (1) prestasi akademik, yaitu nilai raport dan nilai kelulusan memenuhi standar yang ditentukan, (2) memiliki nilainilai kejujuran, ketaqwaan, kesopanan, dan mampu mengapresiasi nialai-nilai budaya, dan (3) memiliki tanggung jawab yang tinggi, dan kemampuan yang diwujudkan dalam bentuk ketrampilan, sesuai dengan standar ilmu yang diterimanya di sekolah (Syaiful Sagala, 2009:170). Pendidikan yang bermutu adalah pendidikan yang dapat menghasilkan peserta didikyang memiliki kemampuan, wawasan, dan ketrampilan sesuai dengan standar yang ditetapkan, sehingga memiliki peluang yang cukup untuk berkompetensi di pasar kerja manapun dengan tidak mengesampingkan aspek-aspek moral dalam kehidupannya.

Indikator utama dalam menentukan tinggi rendahnya kualitas pendidikan, yaitu: dana pendidikan, kelulusan pendidikan, dan prestasi yang dicapai dalam membaca komprehensif. Pertama, pendidikan yang berkualitas tidak mungkin dicapai tanpa dana yang cukup. Kedua, pendidikan yang berkualitas cenderung dapat menghasilkan angka kelulusan yang cukup tinggi. Tentu saja kriteria kelulusan ini dengan angka yang sudah distandarkan. Ketiga, kemampuan membaca komprehensif di negara berkembang cenderung lebih rendah daripada di negara maju, hal ini disebabkan kebiasaan anak-anak menghafal dalam belajar (Mansur dan Mahfud Junaidi, 2005:165).

Kualitas pendidikan dapat dilihat dari segi proses dan produknya. Pertama, suatu pendidikan disebut bermutu dilihat dari segi proses, juga sangat dipengaruhi oleh kualitas masukannya atau disebut input. Proses belajar mengajar dikatakan efektif, apabila selama proses belajar mengajar berlangsung, peserta didikmengalami proses pembelajaran yang bermakna. Dalam hal ini proses pendidikan tidak hanya berjalan dengan lancar dan baik, melainkan proses pendidikan, khususnya proses pembelajaran dapat memposisikan peserta didiksebagai subyek yang mendapatkan perlakuan secara humanistik, sehingga peserta didikmerasa memiliki kebebasan yang cukup untuk mengekspresikan segala potensinya. Kedua, pendidikan disebut berkualitas dari segi produk, jika peserta didikmenunjukkan ciriciri diantaranya penguasaan yang tinggi terhadap tugas-tugas belajar, hasil pendidikannya sesuai atau relevan dengan tuntutan lingkungan, khususnya dunia kerja. Disamping itu, tidak kalah penting adalah kemampuan dan ketrampilan kerja, yang sesuai dengan tuntutan hidup dalam masyarakat, sehingga lulusan pendidikan apapun levelnya dapat menunjukkan kemandirian yang tangguh.

Dewasa ini semua lembaga pendidikan berorientasi pada mutu. Lembaga pendidikan dikatakan bermutu jika input, proses dan hasilnya dapat memenuhi persyaratan yang dituntut oleh pengguna jasa pendidikan. Bila performance-nya dapat melebihi persyaratan yang dituntut oleh stakeholder (user), maka dikatakan unggul. Lantaran tuntutan persyaratan yang dikehendaki para pengguna jasa terus berubah dan berkembang kualitasnya, maka pengertian mutu juga bersifat dinamis, terus berkembang dan terus berada dalam persaingan yang terusmenerus.

Sehubungan dengan hal itu, ada beberapa indikator pendidikan yang bermutu, antara lain:

a. Hasil akhir pendidikan merupakan tujuan akhir pendidikan. Dari hasil tersebut diharapkan para lulusan dapat memenuhi tuntutan masyarakat bila ia bekerja atau melanjutkan studi 
CENDEKIA, Vol. 9, No. 1, April 2015

p ISSN: 1978 2098; e ISSN: 2407 8557; Web: cendekia.pusatbahasa.or.id

Pusat Kajian Bahasa dan Budaya, Surakarta, Indonesia

Zahro, Aminatul. 2015. Total Quality Management: Capaian Kualitas Output melalui Sistem Kontrol Mutu Sekolah. Cendekia, 9(1): 79 94.

ke lembaga pendidikan yang lebih tinggi.

b. Hasil langsung pendidikan. Hasil langsung pendidikan itu berupa: pengetahuan, sikap, dan keterampilan. Hasil inilah yang sering digunakan sebagai kriteria keberhasilan pendidikan.

c. Proses pendidikan. Proses pendidikan merupakan interaksi antara raw input, instrumental input, dan lingkungan, untuk mencapai tujuan pendidikan. Pada proses ini, tidak berbicara mengenai wujud gedung sekolah dan alat-alat pelajaran, akan tetapi bagaimana mempergunakan gedung dan fasilitas lainnya agar peserta didikdapat belajar dengan baik.

d. Instrumental input. Terdiri dari tujuan pendidikan, kurikulum, fasilitas dan media pendidikan, sistem administrasi pendidikan, guru, sistem penyampaian, evaluasi, serta bimbingan dan penyuluhan. Instrumental input tersebut harus dapat berinteraksi dengan raw input (peserta didik) dalam proses pendidikan.

e. Raw input dan lingkungan, juga mempengaruhi kualitas mutu pendidikan (Muhammad Nurdin, 2005:79-80).

Sementara itu parameter bagi sebuah lembaga pendidikan bermutu, yaitu: (1) Terbangunnya paradigma akademik dan juga wawasan akademik dalam lembaga pendidikan, (2) Akuntabilitas, (3) Evaluasi diri, (4) Akreditasi, (5) Kompetensi, (6) SDM yang profesional, (7) Perpustakaan dan laboratorium yang memadai, dan (8) Lingkungan akademik (Mastuhu, 2003:24). Mutu pendidikan harus diupayakan untuk mencapai kemajuan yang dilandasi oleh suatu perubahan secara terencana, mutu pendidikan harus mengutamakan pelajar atau program perbaikan sekolah yang dilakukan secara kreatif dan konstruktif oleh pihak lembaga pendidikan.

\section{Pengendalian Mutu Pendidikan}

Pengendalian mutu adalah suatu usaha yang dilakukan oleh sekolah untuk mengendalikan laju atau jalannya mutu sesuai dengan kemampuan masing-masing lembanga pendidikan. Dalam mengontrol mutu kita juga harus melakukan kendali mutu. Kontrol mutu pendidikan dapat diselenggarakan melalui berbagai model manajemen kendali mutu. Salah satu model manajemen yang dapat digunakan adalah model PDCA (plan, do, check, action) yang akan menghasilkan pengembangan berkelanjutan mutu pendidikan (education quality). Pada tahap check terdapat titik kendali mutu dimana dalam titik ini setiap pelaksana pendidikan di sekolah harus mengaudit hasil pelaksanaan tugasnya dengan standar mutu yang telah ditetapkan.

Setiap lembaga pendidikan atau sekolah selalu berusaha untuk mengendalikan mutu sesuai dengan keadaan dan kemampuan masing-masing lembaga pendidikan. Hal ini bertujuan untuk mempermudah dalam usaha pengendalian mutu itu sendiri. Usaha pengendalian mutu sekolah dapat dilakukan dengan: Pertama, pengendalian mutu tidak dapat menghasilkan suatu manfaat yang optimal. Kedua, usaha tersebut merupakan suatu kegiatan manajemen ilmiah yang ditujukan kepada sasaran tertentu dengan mengikuti siklus manajemen. Ketiga, pengendalian mutu merupakan usaha memperbaiki kualitas lulusan (output). Keempat, pengendalian mutu merupakan usaha untuk mengikuti siklus manajemen yang di kemukakan oleh Deming dengan mempertimbangkan unsur $5 \mathrm{M}$. Unsur $5 \mathrm{M}$ tersebut yaitu: manusia (man), mesin (machine), bahan (material), uang (money), dan metode 
CENDEKIA, Vol. 9, No. 1, April 2015

p ISSN: 1978 2098; e ISSN: 2407 8557; Web: cendekia.pusatbahasa.or.id Pusat Kajian Bahasa dan Budaya, Surakarta, Indonesia

Zahro, Aminatul. 2015. Total Quality Management: Capaian Kualitas Output melalui Sistem Kontrol Mutu Sekolah. Cendekia, 9(1): 79 94.

(method). Kelima, melalui cara perumusan manajemen yang lebih ilmiah yaitu dengan pendekatan ilmiah serta menggunakan data dan fakta. Keenam, melalui implikasi dari pengendalian mutu dalam penjaminan mutu (quality assurance) dengan melalui berbagai model manajemen kendali mutu sesuai dengan situasi dan kondisi yang dihadapi oleh masingmasing lembaga pendidikan atau sekolah (Shigeru Mizuno, 1993:13-14).

\section{Kebijakan Pemerintah Kualitas Output Melalui Kontrol Mutu}

Peraturan pemerintah (Permen) No. 23 Tahun 2006 tentang Standar Kompetensi Lulusan (SKL) untuk Satuan Pendidikan Dasar dan Menengah Pasal 1 menyebutkan bahwa standar kompetensi lulusan untuk satuan pendidikan dasar dan menengah digunakan sebagai pedoman penilaian dalam menentukan kelulusan peserta didik.

Sedangkan pada lampiran Peraturan Menteri Pendidikan Nasional (Permendiknas) No. 23 Tahun 2006 Tanggal 23 Mei 2006 tentang Standar Kompetensi Lulusan (SKL) Satuan Pendidikan (SKL-SP) yaitu: Pertama, untuk SD/MI/SDLB/paket A. Kedua, SMP/MTs/SMPLB/paket B. Ketiga, SMA/MA/SMALB/paket C. Keempat, SMK/MAK. Berikut uraiannya masing-masing SKL per satuan pendidikan adalah:

\section{a. SD/MI/SDLB/paket A}

1) Menjalankan ajaran agama yang dianut sesuai dengan tahapperkembangan anak.

2) Mengenal kekurangan dan kelebihan diri sendiri.

3) Mematuhi aturan-aturan sosial yang berlaku dalam lingkungannya.

4) Menghargai keberagaman agama, budaya, suku, ras, dan golongan sosial ekonomi di lingkungan sekitarnya.

5) Menggunakan informasi tentang lingkungan sekitar secara logis, kritis,dan kreatif.

6) Menunjukkan kemampuan berpikir logis, kritis, dan kreatif, denganbimbingan guru/pendidik.

7) Menunjukkan rasa keingintahuan yang tinggi dan menyadari potensinya.

8) Menunjukkan kemampuan memecahkan masalah sederhana dalamkehidupan sehari-hari.

9) Menunjukkan kemampuan mengenali gejala alam dan sosial di lingkungansekitar.

10) Menunjukkan kecintaan dan kepedulian terhadap lingkungan.

11) Menunjukkan kecintaan dan kebanggaan terhadap bangsa, negara, dantanah air Indonesia.

12) Menunjukkan kemampuan untuk melakukan kegiatan seni dan budayalokal.

13) Menunjukkan kebiasaan hidup bersih, sehat, bugar, aman, danmemanfaatkan waktu luang.

14) Berkomunikasi secara jelas dan santun.

15) Bekerja sama dalam kelompok, tolong-menolong, dan menjaga diri sendiridalam lingkungan keluarga dan teman sebaya.

16) Menunjukkan kegemaran membaca dan menulis.

17) Menunjukkan keterampilan menyimak, berbicara, membaca, menulis, dan berhitung.

b. SMP/MTs/SMPLB/paket B

1) Mengamalkan ajaran agama yang dianut sesuai dengan tahap perkembangan remaja.

2) Memahami kekurangan dan kelebihan diri sendiri.

3) Menunjukkan sikap percaya diri. 
CENDEKIA, Vol. 9, No. 1, April 2015

p ISSN: 1978 2098; e ISSN: 2407 8557; Web: cendekia.pusatbahasa.or.id Pusat Kajian Bahasa dan Budaya, Surakarta, Indonesia

Zahro, Aminatul. 2015. Total Quality Management: Capaian Kualitas Output melalui Sistem Kontrol Mutu Sekolah. Cendekia, 9(1): 79 94.

4) Mematuhi aturan-aturan sosial yang berlaku dalam lingkungan yang lebihluas.

5) Menghargai keberagaman agama, budaya, suku, ras, dan golongan sosialekonomi dalam lingkup nasional.

6) Mencari dan menerapkan informasi dari lingkungan sekitar dan sumber-sumberlain secara logis, kritis, dan kreatif.

7) Menunjukkan kemampuan berpikir logis, kritis, kreatif, dan inovatif.

8) Menunjukkan kemampuan belajar secara mandiri sesuai dengan potensiyang dimilikinya.

9) Menunjukkan kemampuan menganalisis dan memecahkan masalah dalamkehidupan sehari-hari.

10) Mendeskripsi gejala alam dan sosial.

11) Memanfaatkan lingkungan secara bertanggung jawab.

12) Menerapkan nilai-nilai kebersamaan dalam kehidupan bermasyarakat,berbangsa, dan bernegara demi terwujudnya persatuan dalam NegaraKesatuan Republik Indonesia.

13) Menghargai karya seni dan budaya nasional.

14) Menghargai tugas pekerjaan dan memiliki kemampuan untuk berkarya

15) Menerapkan hidup bersih, sehat, bugar, aman, dan memanfaatkan waktuluang.

16) Berkomunikasi dan berinteraksi secara efektif dan santun.

17) Memahami hak dan kewajiban diri dan orang lain dalam pergaulan dimasyarakat.

18) Menghargai adanya perbedaan pendapat.

19) Menunjukkan kegemaran membaca dan menulis naskah pendek sederhana.

20) Menunjukkan keterampilan menyimak, berbicara, membaca, dan menulisdalam bahasa Indonesia dan bahasa Inggris sederhana.

21) Menguasai pengetahuan yang diperlukan untuk mengikuti pendidikan menengah.

c. SMA/MA/SMALB/paket C

1) Berperilaku sesuai dengan ajaran agama yang dianut sesuai dengan perkembangan remaja.

2) Mengembangkan diri secara optimal dengan memanfaatkan kelebihan diri serta memperbaiki kekurangannya.

3) Menunjukkan sikap percaya diri dan bertanggung jawab atas perilaku, perbuatan, dan pekerjaannya.

4) Berpartisipasi dalam penegakan aturan-aturan sosial.

5) Menghargai keberagaman agama, bangsa, suku, ras, dan golongan sosial ekonomi dalam lingkup global.

6) Membangun dan menerapkan informasi dan pengetahuan secara logis, kritis, kreatif,dan inovatif.

7) Menunjukkan kemampuan berpikir logis, kritis, kreatif, dan inovatif dalam pengambilan keputusan.

8) Menunjukkan kemampuan mengembangkan budaya belajar untuk pemberdayaan diri.

9) Menunjukkan sikap kompetitif dan sportif untuk mendapatkan hasil yang terbaik.

10) Menunjukkan kemampuan menganalisis dan memecahkan masalah kompleks.

11) Menunjukkan kemampuan menganalisis gejala alam dan sosial.

12) Memanfaatkan lingkungan secara produktif dan bertanggung jawab. 
CENDEKIA, Vol. 9, No. 1, April 2015

p ISSN: 1978 2098; e ISSN: 2407 8557; Web: cendekia.pusatbahasa.or.id Pusat Kajian Bahasa dan Budaya, Surakarta, Indonesia

Zahro, Aminatul. 2015. Total Quality Management: Capaian Kualitas Output melalui Sistem Kontrol Mutu Sekolah. Cendekia, 9(1): 79 94.

13) Berpartisipasi dalam kehidupan bermasyarakat, berbangsa, dan bernegara secara demokratis dalam wadah Negara Kesatuan Republik Indonesia (NKRI).

14) Mengekspresikan diri melalui kegiatan seni dan budaya.

15) Mengapresiasi karya seni dan budaya.

16) Menghasilkan karya kreatif, baik individual maupun kelompok.

17) Menjaga kesehatan dan keamanan diri, kebugaran jasmani, serta kebersihan lingkungan.

18) Berkomunikasi lisan dan tulisan secara efektif dan santun.

19) Memahami hak dan kewajiban diri dan orang lain dalam pergaulan di masyarakat.

20) Menghargai adanya perbedaan pendapat dan berempati terhadap orang lain.

21) Menunjukkan keterampilan membaca dan menulis naskah secara sistematis dan estetis.

22) Menunjukkan keterampilan menyimak, membaca, menulis, dan berbicara dalam bahasa Indonesia dan Inggris.

23) Menguasai pengetahuan yang diperlukan untuk mengikuti pendidikan tinggi.

d. SMK/MAK

1) Berperilaku sesuai dengan ajaran agama yang dianut sesuai dengan perkembangan remaja.

2) Mengembangkan diri secara optimal dengan memanfaatkan kelebihan diriserta memperbaiki kekurangannya.

3) Menunjukkan sikap percaya diri dan bertanggung jawab atas perilaku, perbuatan, dan pekerjaannya.

4) Berpartisipasi dalam penegakan aturan-aturan sosial.

5) Menghargai keberagaman agama, bangsa, suku, ras, dan golongan sosial ekonomi dalam lingkup global.

6) Membangun dan menerapkan informasi dan pengetahuan secara logis,kritis, kreatif, dan inovatif.

7) Menunjukkan kemampuan berpikir logis, kritis, kreatif, dan inovatifdalam pengambilan keputusan.

8) Menunjukkan kemampuan mengembangkan budaya belajar untuk pemberdayaan diri.

9) Menunjukkan sikap kompetitif dan sportif untuk mendapatkan hasil yang terbaik.

10) Menunjukkan kemampuan menganalisis dan memecahkan masalahkompleks.

11) Menunjukkan kemampuan menganalisis gejala alam dan sosial.

12) Memanfaatkan lingkungan secara produktif dan bertanggung jawab.

13) Berpartisipasi dalam kehidupan bermasyarakat, berbangsa, dan bernegara secara demokratis dalam wadah Negara Kesatuan Republik Indonesia.

14) Mengekspresikan diri melalui kegiatan seni dan budaya.

15) Mengapresiasi karya seni dan budaya.

16) Menghasilkan karya kreatif, baik individual maupun kelompok.

17) Menjaga kesehatan dan keamanan diri, kebugaran jasmani, sertakebersihan lingkungan.

18) Berkomunikasi lisan dan tulisan secara efektif dan santun.

19) Memahami hak dan kewajiban diri dan orang lain dalam pergaulan dimasyarakat.

20) Menghargai adanya perbedaan pendapat dan berempati terhadap orang lain.

21) Menunjukkan keterampilan membaca dan menulis naskah secarasistematis dan estetis. 
CENDEKIA, Vol. 9, No. 1, April 2015

p ISSN: 1978 2098; e ISSN: 2407 8557; Web: cendekia.pusatbahasa.or.id Pusat Kajian Bahasa dan Budaya, Surakarta, Indonesia

Zahro, Aminatul. 2015. Total Quality Management: Capaian Kualitas Output melalui Sistem Kontrol Mutu Sekolah. Cendekia, 9(1): 79 94.

22) Menunjukkan keterampilan menyimak, membaca, menulis, dan berbicaradalam bahasa Indonesia dan Inggris.

23) Menguasai kompetensi program keahlian dan kewirausahaan baik untuk memenuhi tuntutan dunia kerja maupun untuk mengikuti pendidikan tinggi sesuai dengan kejuruannya (Permendiknas, 2006:1-5).

\section{PENUTUP}

Untuk mendukung kebijakan pemerintah ini, maka untuk mewujukan output yang berkualitas langkah yang digunakan yaitu membangun mutu di setiap institusi pendidikan dengan komitmen bersama. Pimpinan lembaga pendidikan atau sekolah harus mulai membaca kecenderungan masyarakat kedepan, kemudian merancang strategi baru terkait kualitas atau mutu lulusan melalui sistem kontrol mutu sekolah.

Dari uraian di atas dapat disimpulkan bahwa kualitas output berada di dalam pendidikan yang bermutu. Pendidikan yang bermutu ditentukan oleh beberapa komponen yang terkait mualai dari input (masukan), proses, dan output (keluaran), serta dengan pengelolaan manajemen yang terorganisir dengan baik dan total. Ketotalan dalam manajemen akan membawa pada kualitas yang mampu mewujudkan visi, misi, dan tujuan sekolah. TQM melalui sistem kontrol mutu bertujuan untuk menjadikan lulusan yang bermutu, dan berkualitas serta mampu berdaya saing. Perbaikan kualitas output ini tidak hanya menjadi program sekolah saja tetapi juga menjadi program pemerintah.

\section{DAFTAR PUSTAKA}

Arcaro, Jarome S. 2007. Pendidikan Berbasis Mutu: Prinsip-Prinsip Perumusan dan Tata Langkah Penerapan, Terjemahan Yosai Triantara, Yogyakarta: Pustaka Pelajar.

Burhanuddin dkk. 2002. Manajemen Pendidikan. Malang: Universitas Negeri Malang.

Departemen Pendidikan Nasional, Permen No. 23 Tahun 2006 tentang Standar Kompetensi Lulusan Untuk Satuan Pendidikan Dasar dan Menengah.

Fadjar,A. Malik. 2005. Holistika Pemikiran Pendidikan, ed. Ahmad Barizi, Jakarta: PT. Raja Grafindo Persada.

Fatah, Nanang. 2000. Ekonomi dan Pembiayaan Pendidikan, Bandung: Remaja Rosdakarya.

Faustno, Cardaso Gorton. 2002. Manajemen Sumber Daya Manusia, Yogyakarta: Andi.

Hasan,M. Ali, dan Mukti Ali, Kapita Selekta Pendidikan Islam, Jakarta: Pedoman Ilmu Jaya, 2003.

Hedwig, Rinda, dan Gerardus Polla.2006. Model Sistem Penjaminan Mutu dan ProsesPenerapannya di Perguruan Tinggi, Yogyakarta: Graha Ilmu,.

Mansur dan Mahfud Junaidi. 2005. Rekontruksi Sejarah Pendidikan Islam di Indonesia, Jakarta: Departemen Agama RI Dirjen Kelembagaan Agama Islam.

Mastuhu, 2003. Menata Ulang Sistem Pendidikan Nasional dalam Abad 21, Yogyakarta: Safira Insani Press.

Mizuno, Shigeru, 1993. Sejarah Pengendalian Mutu Terpadu di Jepang, Terjemahan Eko Henryanto dan BN Marbun, Pengendalian Mutu Terpadu, Jakarta; PT Gramedia.

Muhaimin, 2005. Manajemen Penjaminan Mutu di Universitas Islam Malang, Malang: UIN Press. 
CENDEKIA, Vol. 9, No. 1, April 2015

p ISSN: 1978 2098; e ISSN: 2407 8557; Web: cendekia.pusatbahasa.or.id Pusat Kajian Bahasa dan Budaya, Surakarta, Indonesia

Zahro, Aminatul. 2015. Total Quality Management: Capaian Kualitas Output melalui Sistem Kontrol Mutu Sekolah. Cendekia, 9(1): 79 94.

Mulyasana, Dedy, 2011. Pendidikan Bermutu dan Berdaya Saing, Bandung: Remaja Rosdakarya.

Nasution,M. N. 2001. Manajemen Mutu Terpadu (Total Quality Management), Jakarta: Ghalia Indonesia.

Sagala, Syaiful. 2009. Manajemen Strategik Dalam Peningkatan Mutu Pendidikan: Pembuka Ruang Kreativitas, Inovasi, dan Pemberdayaan Potensi Sekolah dalam Sistem Otonomi Sekolah, Bandung: Alfabeta.

Sallis, Edward. 2006. Total Quality Management In Education, Terjemahan Ahmad Ali RiyadiFahrurrozi, Yogyakarta: IRCiSoD.

Shaleh, Abdul Rachman. 2006. Madrasah dan Pendidikan Anak Bangsa Visi, Misi, dan Aksi, Jakarta: Raja Grafindo Persada.

Sudjono. 2000. Manajemen Program Pendidikan Untuk Pendidikan Luar Sekolah dan Pengembangan Sumber Daya Manusia, Bandung: Falah Production.

Sujanto, Bedjo. 2007. Guru Indonesia dan Perubahan Kurikulum: Mengorek Kegelisahan Guru, Jakarta: Sagung Seto.

Syafaruddin. 2002. Manajemen Mutu Terpadu dalam Pendidikan: Konsep, Strategi dan Aplikasi, Jakarta: Grasindo.

Tjiptono, Fandy, dan Anastasia Diana. 2003. Total Quality Management, Yogyakarta: Andi.

Usman, Husaini, 2006. Manajemen:Teori, Praktik dan Riset Pendidikan, Jakarta: Bumi Aksara.

Winata, Ali, 2006. Sistem Penjaminan Mutu Pendidikan, Bandung: Pustaka Setia.

Yunus, Falah,Manajemen Peningkatan Mutu Pendidikan.http://www.duniaguru.com/index.php?option=com_content\&task=view\&id=176 \&Itemid=4 0, diakses 3 April 2015.

Zahroh, Aminatul, 2014. Total Quality Management: Teori \& Praktik Manajemen Untuk Mendongkrak Mutu Pendidikan, Yogyakarta: Ar-Ruzz Media. 